\title{
Phosphorus dynamics and limitation of fast- and slow-growing temperate seaweeds in Oslofjord, Norway
}

\author{
Morten Foldager Pedersen ${ }^{1, *}$, Jens Borum², Frank Leck Fotel ${ }^{1}$ \\ ${ }^{1}$ Department of Environmental, Social \& Spatial Change (ENSPAC), Roskilde University, Box 260, 4000 Roskilde, Denmark \\ ${ }^{2}$ Freshwater Biological Laboratory, Biological Institute, University of Copenhagen, Helsingørsgade 51, 3400 Hillerød, Denmark
}

\begin{abstract}
During coastal eutrophication, fast-growing, ephemeral macroalgae bloom at the expense of slow-growing, perennial macroalgae. This change in community composition has been explained by a differential ability to exploit and utilize inorganic nitrogen among macroalgae with different growth strategies. However, some coastal areas are becoming phosphorus- rather than nitrogen-limited; we therefore compared phosphorus dynamics among 6 temperate species of macroalgae with different growth rates in order to test whether differences in algal P-dynamics may explain macroalgal community changes. Thin, fast-growing algae (Ulva and Ceramium) took up dissolved inorganic P (DIP) much faster than thicker, slower growing species (belonging to Fucus, Ascophyllum and Laminaria) but also had much higher P-demands per unit biomass and time. DIP concentrations in the Oslofjord were low from April through August, and fast-growing species were unable to meet their P-demand from uptake for several months during summer. Hence, Ceramium and Ulva were potentially P-limited during summer, whereas Ascophyllum and Laminaria were able to acquire sufficient external DIP to remain P-replete throughout the year. Storage of P prevented Fucus species from suffering severe P-limitation for several weeks in summer. The absolute amount of P stored within the algae per unit biomass did not differ systematically among the 6 species, but the storage capacity (i.e. the period of time for which stored P could support growth) was much larger for slower growing species since this parameter depended heavily on realized growth rate. Our results show how differences in macroalgal P-dynamics may explain the changing balance among macroalgae with different growth strategies in P-deficient coastal areas.
\end{abstract}

KEY WORDS: Macroalgae $\cdot$ Seaweeds $\cdot$ Nutrient dynamics $\cdot$ Phosphorus $\cdot$ Eutrophication

\section{INTRODUCTION}

Low availability of nutrients can limit growth and biomass of marine macroalgae, and therefore coastal eutrophication causes structural changes in the macroalgal assemblages (e.g. Duarte 1995, Borum \& Sand-Jensen 1996, Valiela et al. 1997, Schramm 1999, Kraufvelin et al. 2006, Kraufvelin et al. 2009). These changes include accumulation of fast-growing foliose or filamentous algae (Fletcher 1996, Karez et al. 2004) and loss of benthic, slow-growing, perennial algae and seagrasses (e.g. Kautsky et al. 1986, Vogt \& Schramm 1991, Bokn et al. 1992, Eriksson et al. 1998,
Nielsen et al. 2002b). Growth of fast-growing algae seems more directly coupled to the instantaneous availability of nutrients, and several studies have shown that these algae are more nutrient-limited than slow-growing perennial algae under nutrient-poor conditions (e.g. Pedersen 1995, Pedersen \& Borum 1996). Hence, nutrient enrichment will stimulate fastgrowing algae proportionally more than slow-growing algae; in turn, slow growing algae may suffer from shading caused by the increasing biomass of phytoplankton, periphyton and free-floating ephemeral macroalgae (Sand-Jensen \& Borum 1991, Nielsen et al. 2002a,b). 
Most studies on nutrient dynamics in temperate seaweeds concern nitrogen because it is believed to be the major limiting nutrient to plant growth in temperate coastal ecosystems, while phosphorus is recognized as being the main limiting nutrient for aquatic plant growth in tropical areas and in areas with carbonate rich sediments (Howarth 1988, Lapointe et al. 1992, Nixon 1995, Howarth \& Marino 2006). Effective treatment of urban sewage during the last 20 to $30 \mathrm{yr}$ has reduced the emission of anthropogenic phosphorus to the coastal zone in many temperate areas (Conley et al. 2000, Kronvang et al. 2005). The emission of nitrogen has not been reduced to the same degree, and phosphorus is therefore becoming more important as a limiting nutrient in some areas where nitrogen would otherwise be expected to be the major limiting nutrient (e.g. Venice Lagoon, Italy; Sfriso \& Marcomini 1996). Such changes make it relevant to study P-dynamics in temperate macroalgae in order to understand how variations in the availability of inorganic $\mathrm{P}$ may affect growth of algae with different life strategies (i.e. fastgrowing versus slow-growing species). Several studies have examined P-uptake kinetics in macroalgae (Odum et al. 1958, Wallentinus 1984, O'Brien \& Wheeler 1987, Hurd \& Dring 1990, Gordillo et al. 2002, Runcie et al. 2004), but few have compared growthrelated P-requirements to uptake kinetics and storage capacity in more than 1 or 2 species at a time (but see Gordon et al. 1981, Manley \& North 1984, Björnsäter \& Wheeler 1990, Lavery \& McComb 1991).

Slow-growing perennial algae belonging to the genera Fucus, Ascophyllum, and Laminaria often dominate inter-tidal and sub-tidal communities of northern temperate rocky shores. This is also the case in Oslofjord (Norway), although fast-growing opportunistic species may be abundant close to nutrient point sources and/or in sheltered areas (Rueness \& Fredriksen 1991, Bokn et al. 1992). The concentration of dissolved inorganic phosphorus (DIP) in Oslofjord is low by northern European standards, both in terms of absolute concentration and concentration relative to dissolved inorganic nitrogen. Concentrations of DIP range from 0.1 to $0.4 \mu \mathrm{M}$ during the main growth season (i.e. April to October), which is lower than half the saturation constants for Puptake in many macroalgae (typically ranging between 0.5 and $10 \mu \mathrm{M}$; e.g. Wallentinus 1984, Hurd \& Dring 1990). Most macroalgae in Oslofjord are therefore expected to suffer P-limitation during summer unless they have a very high affinity for DIP at low substrate concentrations or can rely on stored phosphorus taken up during winter when nutrient concentrations are typically much higher than in summer.

In this study, we compare P-dynamics of 6 macroalgal species that are common members of the macroalgal assemblage in Oslofjord and in other temperate coastal areas. The species were chosen to represent different growth strategies: Ceramium rubrum and Ulva lactuca represented fast-growing ephemeral algae, Fucus vesiculosus and Fucus serratus represented perennial algae having intermediate growth rates, and Ascophyllum nodosum and Laminaria digitata represented slowly growing perennial algae. More specifically, we wanted to compare whether growth related P-demands, P-uptake kinetics and P-storage capacities differed systematically among the 3 groups of algae. The results are discussed in relation to the importance of nutrient (phosphorus) richness for macroalgal community composition in temperate coastal areas.

\section{MATERIALS AND METHODS}

Experimental enrichment of macroalgae. The study was conducted as part of the EULIT project (Bokn et al. 2001, 2003) which was carried out using 8 land-based mesocosms designed for hard-bottom littoral communities at the Marine Research Station, Solbergstrand near Dröbak (Oslofjord, Norway). Each mesocosm contained from 6 to $12 \mathrm{~m}^{3}$ of seawater (at low and high tide, respectively) and was fed with water from the fjord at a rate of $5 \mathrm{~m}^{3} \mathrm{~h}^{-1}$ (equivalent to a turnover rate of 0.4 to $0.8 \mathrm{~h}^{-1}$ ). Initially, each mesocosm contained well established inter-tidal communities identical to those in Oslofjord. Nutrient enrichment was initiated in May 1998 and lasted to the end of 2000. Nitrogen and phosphorus were continuously added to 6 of the 8 basins from stock solutions of $\mathrm{NH}_{4} \mathrm{NO}_{3}$ and $\mathrm{H}_{3} \mathrm{PO}_{4}$ to yield concentrations of $1,2,4,8,16$ and $32 \mu \mathrm{M}$ dissolved inorganic nitrogen (DIN) and 0.06, 0.12, 0.25, $0.5,1.0$ and $2.0 \mu \mathrm{M}$ dissolved inorganic phosphorus (DIP) above background levels. Two mesocosms received no extra nutrients ('ambient levels'). Water temperature, salinity and incident light were recorded continuously; concentrations of DIN and DIP were measured 3 to 4 times weekly in the water of each mesocosm, as well as in the water entering the mesocosms from Oslofjord. A technical description of the mesocosms, associated facilities, nutrient levels achieved in the mesocosms and the biological communities is provided by Bokn et al. (2001, 2003).

Algae were collected in the mesocosms in JulyAugust 2000. Sub-samples of each species were further kept for $2 \mathrm{wk}$ in small (60 1), translucent tanks filled with water from Oslofjord (and without water exchange) to obtain algae with tissue P-concentrations lower than those in algae from the control mesocosms. The ratio of algae to the volume of water in these tanks were kept high to ensure rapid depletion of DIP from the water, but sufficiently low to prevent substantial self-shading; tanks were kept floating in the meso- 
cosms to maintain the same water temperature and light conditions as in the mesocosms themselves.

Maximum photosynthetic rates and calculation of growth rates. Light saturated photosynthesis was used as a proxy for maximum growth rate. Photosynthetic rates of Ulva lactuca, Ceramium rubrum, Fucus vesiculosus, Fucus serratus, Ascophyllum nodosum and Laminaria digitata were measured from evolution of oxygen at light saturation. Four samples for each species (non-fertile apical pieces for all species except $L$. digitata, where discs with a diameter of $3 \mathrm{~cm}$ taken $5 \mathrm{~cm}$ above the meristem were used) were collected from each mesocosm. Samples were rinsed and kept in seawater (from the mesocosm where they were sampled) under constant light (ca. $300 \mu \mathrm{mol}$ photons $\mathrm{m}^{-2} \mathrm{~s}^{-1} \mathrm{PAR}$ ) and temperature $\left(18^{\circ} \mathrm{C}\right)$ for $12 \mathrm{~h}$ prior to measurements. Algal samples (ca. $0.5 \mathrm{~g} \mathrm{FW)} \mathrm{were} \mathrm{incubated} \mathrm{in}$ $120 \mathrm{ml}$ glass bottles filled with freshly collected and filtered (GF/C, Whatman) seawater from the mesocosms where the algae were collected $([D I C]=$ ca. $2.0 \mathrm{mM}$, $\mathrm{pH}=7.5$ to 8.1). The water was bubbled with $\mathrm{N}_{2}$ to reduce the $\mathrm{O}_{2}$-concentration to about $60 \%$ of air-saturation. Bottles were placed on a vertically oriented rotating wheel (60 cm diameter, $12 \mathrm{rpm}$ ) submerged in a water bath with a translucent front. Water temperature was held constant at $18^{\circ} \mathrm{C}$ (equivalent to the water temperature in the mesocosms in July-August) and illuminated with $480 \mu \mathrm{mol}$ photons $\mathrm{m}^{-2} \mathrm{~s}^{-1}$ photosynthetically active radiation (PAR); enough to saturate photosynthesis of the algae involved (M. F. Pedersen unpubl. data). Light was provided by a lamp covering the translucent front of the water bath. PAR at the surface of the wheel (and the bottles) was measured with a submersible 2-sensor (LI-192SA, Li-Cor). Incubations lasted for 1 to $2 \mathrm{~h}$. Filtered seawater blanks acted as controls. Initial and final concentrations of dissolved $\mathrm{O}_{2}$ were determined by duplicate micro-Winkler titrations (precision: $\pm 0.01 \mathrm{mg} \mathrm{O}_{2} \mathrm{l}^{-1}$ ) and rates of light saturated photosynthesis $\left(P_{\max }\right)$ were estimated from:

$$
P_{\max }=\frac{\left(\left[\mathrm{O}_{2}\right]_{T}-\left[\mathrm{O}_{2}\right]_{0}\right) \times V o l}{D W \times T}
$$

where $\left[\mathrm{O}_{2}\right]_{0}$ and $\left[\mathrm{O}_{2}\right]_{T}$ are the initial and final concentrations of $\mathrm{O}_{2}$, respectively, $\mathrm{Vol}$ is the volume of each bottle, $D W$ is the algal biomass dry weight and $T$ is the incubation time.

Growth rates were calculated from measured photosynthetic rates using photosynthetic quotient $(\mathrm{PQ})$ ratios reported in the literature. We were unable to find species specific PQ-ratios of the algae used in this study, so we used mean values for green, red and brown macroalgae instead (Table 1).
PQ-ratios for algae theoretically range between 1.25 and 1.6 when carbohydrates, lipids, proteins and nucleic acids are produced with either ammonium or nitrate as the N-source (Williams \& Robertson 1991). However, reported PQ-ratios in macroalgae range from 0.63 to 2.7 (Buesa 1980, Thomas \& Wiencke 1991, Rosenberg et al. 1995, Mercado et al. 2003). Median PQ-ratios and associated 10 and $90 \%$ percentiles from these data sets (Table 1) were subsequently used to calculate a range of potential growth rates for each of the species used in this study. Growth rates were estimated assuming exposure to ca. $12 \mathrm{~h}$ of saturating light per day (based on measurements of daily insolation during July and August 2000). Growth rates were calculated in units of $\mathrm{g} \mathrm{C} \mathrm{g}^{-1}$ tissue $\mathrm{C} \mathrm{d}^{-1}$ and transformed to relative growth rates (RGR, unit: $\ln$ units $\mathrm{d}^{-1}$ ) assuming exponential growth.

Tissue nutrient analysis. Algal samples used for photosynthetic measurements were analyzed for tissue $C_{\text {, }}$ $\mathrm{N}$ and $\mathrm{P}$. The samples were cleaned, dried and analyzed for total C and N using a Carlo-Erba NA-1500 $\mathrm{CHN}$ analyzer. Total tissue-P was determined after wet oxidation with boiling $\mathrm{H}_{2} \mathrm{SO}_{4}$ and spectrophotometric analysis following Strickland \& Parsons (1968). Samples of the same species were further collected from each mesocosm at the time of maximum tissue-P (i.e. March to April) in both 1998 and 1999. The tissue concentration of $\mathrm{P}$ in these samples was determined using the same methods as above.

Phosphorus requirements. Species specific Prequirements were estimated from calculated growth rates and critical tissue concentrations of $\mathrm{P}\left(P_{\mathrm{C}}\right)$. The critical tissue concentration of $\mathrm{P}$ required to sustain maximum growth rate was determined from plots of growth rate versus tissue P-concentration (Hanisak 1979). A Droop model was fitted to the data using least-square non-linear regression (SYSTAT v. 11):

$$
\mu=\mu_{\max }^{*}\left(1-\frac{P}{P_{Q}}\right)
$$

where $\mu$ is calculated growth rate, $\mu^{*}{ }_{\max }$ is the maximum growth rate, $P$ is the tissue concentration of $\mathrm{P}$ and

Table 1. PQ-ratios. Review of PQ-ratios used to calculate growth rates from photosynthetic rates (Buesa 1980, Thomas \& Wiencke 1991, Rosenberg et al. 1995, Mercado et al. 2003). The mean PQ-value for brown seaweeds differed significantly from those of green and red seaweeds (ANOVA, $p=0.045$ )

\begin{tabular}{|lcccc|}
\hline & $\begin{array}{c}\text { Green } \\
\text { (Chlorophyta) }\end{array}$ & $\begin{array}{c}\text { Red } \\
\text { (Rhodophyta) }\end{array}$ & $\begin{array}{c}\text { Brown } \\
\text { (Phaeophyta) }\end{array}$ & All \\
\hline Mean & 1.16 & 1.15 & 1.48 & 1.26 \\
Range (min.-max.) & $1.00-1.37$ & $0.63-1.56$ & $0.85-2.70$ & $0.63-2.70$ \\
Median & 1.16 & 1.15 & 1.29 & 1.19 \\
$10-90 \%$ percentiles & $1.01-1.35$ & $0.81-1.50$ & $1.05-2.22$ & $0.92-1.74$ \\
\hline
\end{tabular}


$P_{\mathrm{Q}}$ is the minimum subsistence quota (i.e. the minimum tissue P-concentration needed to sustain growth). Critical tissue $\mathrm{P}$-concentration $\left(P_{\mathrm{C}}\right)$ was estimated from the intercept between the horizontal line representing maximum growth rate and the line representing the initial slope of the curve. P-requirements $\left(P_{\text {req }}\right)$ needed to sustain growth at maximum rates were finally estimated for each species as the product of observed maximum growth rate and critical $\mathrm{P}$ concentration (i.e. $\left.R G R_{\max } \times P_{\mathrm{C}}\right)$.

Uptake kinetics. P-uptake kinetics (i.e. $V_{\max }$ and $K_{\mathrm{m}}$ ) were determined in the laboratory using a combination of the 'multiple flask method' and the 'depletion method' (Harrison et al. 1989, Pedersen 1994). Algal samples ( $\mathrm{n}=6$ for each species) were collected from the control mesocosms, rinsed and kept in fresh seawater under constant irradiance (ca. $300 \mu \mathrm{mol}$ photons $\left.\mathrm{m}^{-2} \mathrm{~s}^{-1} \mathrm{PAR}\right)$ and temperature $\left(18^{\circ} \mathrm{C}\right)$ for $12 \mathrm{~h}$ prior to the measurements. Uptake experiments were carried out in glass beakers containing 21 of freshly collected and filtered seawater kept under constant irradiance $\left(400 \mu \mathrm{mol} \mathrm{m} \mathrm{m}^{-2} \mathrm{~s}^{-1} \mathrm{PAR}\right)$ and temperature $\left(18^{\circ} \mathrm{C}\right)$. Water circulation in the beakers was generated by aeration. The media were enriched with phosphorus by adding $\mathrm{KH}_{2} \mathrm{PO}_{4}$ from stock solutions. The uptake experiments were carried out with 6 different starting concentrations of phosphorus, ranging from 0.5 to $10 \mu \mathrm{M}$ DIP. Algal material (0.3 to $1.3 \mathrm{~g}$ DW) was fixed to a Nitex mesh and submersed in the medium at time $T=0$. Triplicate water samples (each $5 \mathrm{ml}$ ) were collected from each beaker at the onset of the experiment, after $30 \mathrm{~min}, 60 \mathrm{~min}$, and subsequently every hour for the next $4 \mathrm{~h}$. Concentrations of DIP were immediately determined according to Strickland \& Parsons (1968). Algal samples used for uptake measurements were dried to constant weight at $80^{\circ} \mathrm{C}$ and weighed. Uptake rates $\left(V\right.$, $\left[\mu \mathrm{mol} \mathrm{P} \mathrm{g}^{-1} \mathrm{DW} \mathrm{h}^{-1}\right]$ ) were calculated for each sampling interval during the depletion according to:

$$
V=\frac{\left(\left[\mathrm{PO}_{4}\right]_{T}-\left[\mathrm{PO}_{4}\right]_{0}\right) \times V o l}{D W \times T}
$$

where $\left[\mathrm{PO}_{4}\right]_{0}$ and $\left[\mathrm{PO}_{4}\right]_{T}$ are the initial and final concentrations of phosphorus over a sampling interval, Vol is the volume of medium at sampling time $(T)$, and $D W$ is algal dry weight biomass. Uptake rates $(V)$ were plotted against the mean substrate concentration (S) for each time interval, and the Monod function was fitted to the data using non-linear, least squares regression (SYSTAT v. 11):

$$
V=\frac{V_{\max } \times\left[\mathrm{PO}_{4}\right]}{\left(\mathrm{K}_{\mathrm{m}}+\left[\mathrm{PO}_{4}\right]\right)}
$$

where $V_{\max }$ is the maximum uptake rate and $\mathrm{K}_{\mathrm{m}}$ the half-saturation constant. The initial slope of the $V$ versus $\left[\mathrm{PO}_{4}\right]$ curve, approximated by $V_{\max } / \mathrm{K}_{\mathrm{m}}$, was calcu- lated and used as a proxy of the affinity for $\mathrm{P}$ at low substrate concentrations (Healy 1980).

Storage capacity. The absolute amount of $\mathrm{P}$ that could be stored in the algae was estimated from the difference between the highest observed tissue Pconcentration and the critical P-concentration for each species. The storage capacity, here defined as the time by which stored P could support growth without taking up DIP from the surrounding water, was estimated by using growth rate as a dilution rate:

$$
T=\frac{\ln \left(P_{\max }\right)-\ln \left(P_{C}\right)}{\mu}
$$

where $\mu$ is the growth rate, $P_{\max }$ and $P_{\mathrm{C}}$ are the maximum and critical tissue $\mathrm{P}$-concentrations, respectively, and $T$ is the time it takes to lower the tissue P-concentration from $P_{\max }$ to $P_{\mathrm{C}}$ (i.e. the storage capacity).

\section{RESULTS}

\section{Nutrient concentrations in ambient seawater}

Water entering the control mesocosms from Oslofjord was often depleted in DIP relative to DIN during the main growth season (Fig. 1). Ambient concentrations of DIP were low (ca. $0.1 \mu \mathrm{M}$ ) in spring (April to May), and a little higher $(0.2$ to $0.3 \mu \mathrm{M})$ from June to September (Fig. 1). Concentrations of DIP rarely exceeded $1 \mu \mathrm{M}$. Molar DIN:DIP ratios averaged $43.8 \pm$ 2.5 (mean $\pm \mathrm{SD}$ ) on an annual basis, but were higher during summer $($ mean $=51.4$, range $=19.3$ to 96.4), indicating P-deficiency during the main growth season.

\section{Nutrient concentrations in algal tissues}

Tissue concentrations of N (Table 2) in algae kept under ambient conditions (control mesocosms) in July to August 2000 were generally above concentrations expected to limit growth of macroalgae (i.e. 1.5 to $2.0 \%$ $\mathrm{N}$ of DW; Duarte 1992). Tissue concentrations of $\mathrm{N}$ in Ulva lactuca (4.94\% DW) and Ceramium rubrum $(4.42 \%$ DW) were higher than in Ascophyllum nodosum $(2.68 \%$ DW) which was higher than in the 2 Fucus species (1.86 and 2.29\% DW) and Laminaria digitata (1.99\% DW) (ANOVA, $F=73.1, \mathrm{p}<0.001$ ). Tissue concentrations of $\mathrm{P}$ in algae kept under ambient conditions (August 2000) ranged from 0.17\% DW in $A$. nodosum to $0.31 \% \mathrm{DW}$ in C. rubrum. The P-concentration in C. rubrum was significantly higher than in $U$. lactuca $(0.14 \% \mathrm{DW}), F$. serratus $(0.20 \% \mathrm{DW})$ and $L$. digitata $(0.17 \% \mathrm{DW})$, which were higher than that in $F$. vesiculosus (0.12\% DW) (ANOVA, $F=17.2, \mathrm{p}<0.001)$. 

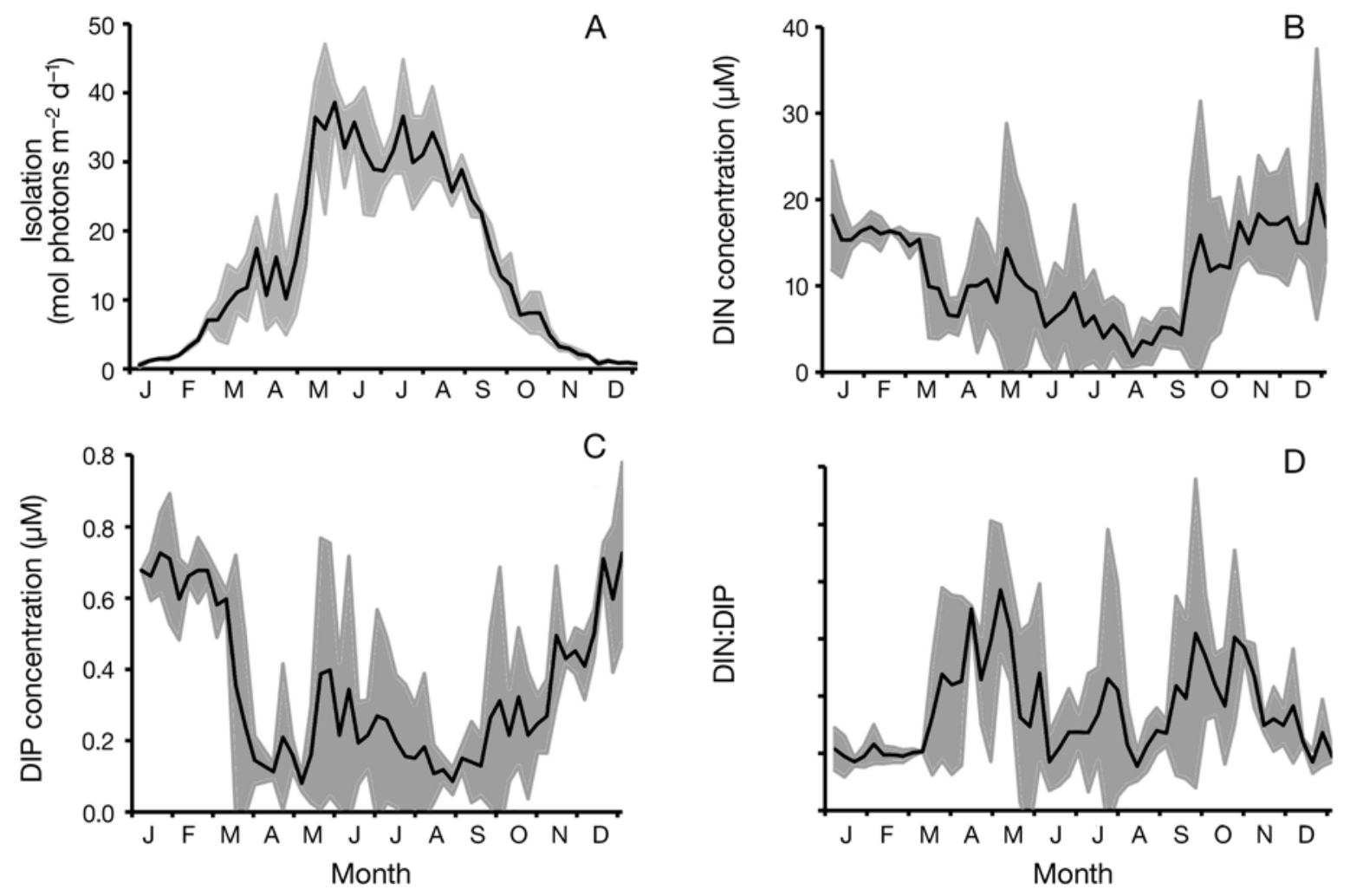

Fig. 1. Seasonal variation in light insolation (PAR), concentrations of dissolved inorganic nitrogen (DIN) and phosphorus (DIP), and molar DIN:DIP ratios in Oslofjord (Norway). Black line: weekly mean values; shaded area: $\pm 95 \%$ CL for 3 years (1998 to 2000)

Molar NP-ratios differed among species (range: 24.9 to 78.9), but only that of $U$. lactuca (78.9) was significantly higher than those in the remaining species (ANOVA, $F=11.0, \mathrm{p}<0.001)$.

\section{Growth rates and P-requirements}

Calculated maximum growth rates $\left(\mathrm{RGR}_{\max }\right)$ obtained at high tissue P-concentrations differed significantly (ANOVA, $F=316.6, \mathrm{p}<0.001$ ) among species (Table 3). Ulva lactuca $\left(0.198 \mathrm{~d}^{-1}\right)$ grew faster (Tukey, $\mathrm{p}<0.001)$ than Ceramium rubrum $\left(0.136 \mathrm{~d}^{-1}\right)$ and both grew much faster (Tukey, $\mathrm{p}<0.001$ ) than the 2 Fucus species $\left(0.040 \mathrm{~d}^{-1}\right)$, Ascophyllum nodosum $\left(0.014 \mathrm{~d}^{-1}\right)$ and Laminaria digitata $\left(0.006 \mathrm{~d}^{-1}\right)$. The 2 Fucus species grew with the same rate (Tukey, p = 1.000) but faster (Tukey, $\mathrm{p}=0.006$ ) than $A$. nodosum and $L$. digitata which both grew at approximately the same rate (Tukey, $\mathrm{p}=0.639$ ).

Growth rates tended to correlate with tissue Pconcentrations in most of the algae (Fig. 2), but not so in Fucus vesiculosus. Critical P-concentrations $\left(P_{\mathrm{C}}\right)$ of all species except $F$. vesiculosus were determined from the plots of RGR versus tissue-P concentrations; the critical P-limit for F. vesiculosus was defined as

Table 2. Tissue levels of carbon $(\mathrm{C})$, nitrogen $(\mathrm{N})$, phosphorus $(\mathrm{P})$ as percent of dry weight and molar C:N, C:P and N:P ratios of macroalgae kept at ambient nutrient levels in August 2000. Data are mean \pm SD $(n=4)$. Superscripted letters indicate groups that are statistically similar according to one-factor ANOVA and Tukey's test

\begin{tabular}{|lcccccc|}
\hline Species & $\% \mathrm{C}$ & $\% \mathrm{~N}$ & $\% \mathrm{P}$ & $\mathrm{C}: \mathrm{N}$ & $\mathrm{C}: \mathrm{P}$ & $\mathrm{N}: \mathrm{P}$ \\
\hline Ulva lactuca & $33.3 \pm 1.8^{\mathrm{a}}$ & $4.94 \pm 1.85^{\mathrm{a}}$ & $0.14 \pm 0.03^{\mathrm{b}}$ & $8.7 \pm 2.7^{\mathrm{a}}$ & $627 \pm 120^{\mathrm{b}}$ & $78.9 \pm 29.9^{\mathrm{a}}$ \\
Ceramium rubrum & $31.3 \pm 1.3^{\mathrm{a}}$ & $4.42 \pm 0.47^{\mathrm{a}}$ & $0.31 \pm 0.08^{\mathrm{a}}$ & $8.3 \pm 0.6^{\mathrm{a}}$ & $273 \pm 58^{\mathrm{a}}$ & $32.8 \pm 6.5^{\mathrm{b}}$ \\
Fucus vesiculosus & $36.0 \pm 0.7^{\mathrm{b}}$ & $1.86 \pm 0.12^{\mathrm{c}}$ & $0.12 \pm 0.01^{\mathrm{c}}$ & $22.6 \pm 1.6^{\mathrm{b}}$ & $762 \pm 58^{\mathrm{b}}$ & $33.7 \pm 2.5^{\mathrm{b}}$ \\
Fucus serratus & $37.5 \pm 1.3^{\mathrm{b}}$ & $2.29 \pm 0.23^{\mathrm{c}}$ & $0.20 \pm 0.06^{\mathrm{b}}$ & $19.3 \pm 2.3^{\mathrm{b}}$ & $522 \pm 169^{\mathrm{b}}$ & $26.5 \pm 5.8^{\mathrm{b}}$ \\
Ascophyllum nodosum & $37.8 \pm 1.8^{\mathrm{b}}$ & $2.68 \pm 1.44^{\mathrm{b}}$ & $0.17 \pm 0.09^{\mathrm{b}}$ & $22.2 \pm 12.6^{\mathrm{b}}$ & $826 \pm 565^{\mathrm{c}}$ & $36.7 \pm 5.6^{\mathrm{b}}$ \\
Laminaria digitata & $36.4 \pm 1.4^{\mathrm{b}}$ & $1.99 \pm 0.16^{\mathrm{c}}$ & $0.17 \pm 0.06^{\mathrm{b}}$ & $21.7 \pm 1.3^{\mathrm{b}}$ & $606 \pm 203^{\mathrm{b}}$ & $24.9 \pm 8.8^{\mathrm{b}}$ \\
\hline
\end{tabular}


Table 3. Calculated maximum growth rates $\left(\mathrm{RGR}_{\max }\right)$, critical P-limits $\left(\mathrm{P}_{\mathrm{C}}\right)$, and estimated P-requirements at maximum growth in 6 species of macroalgae. Growth rates are mean \pm SD $(n=4)$. Superscripted letters indicate groups that are statistically similar according to one-factor ANOVA and Tukey's test. Parentheses: range of growth rates and P-requirements obtained by using a range of $\mathrm{PQ}$-values to estimate growth rate from photosynthesis

\begin{tabular}{|c|c|c|c|}
\hline Species & $\begin{array}{l}\text { Max. growth rate } \\
\qquad\left(\ln \text { units d } d^{-1}\right)\end{array}$ & $\begin{array}{c}\text { Critical tissue } \\
\text { P-concentration } \\
\left(\mu \mathrm{mol} \mathrm{P} \mathrm{g}^{-1} \mathrm{DW}\right)\end{array}$ & $\begin{array}{l}\text { P-requirements } \\
\text { for max. growth } \\
\left(\mu \mathrm{mol} \mathrm{P} \mathrm{g}^{-1} \mathrm{DW} \mathrm{d}^{-1}\right)\end{array}$ \\
\hline Ulva lactuca & $\begin{array}{c}0.196 \pm 0.018^{\mathrm{a}} \\
(0.171 \pm 0.016-0.225 \pm 0.018)\end{array}$ & 65.5 & $\begin{array}{c}12.8 \\
(11.2-14.7)\end{array}$ \\
\hline Ceramium rubrum & $\begin{array}{c}0.136 \pm 0.012^{\mathrm{b}} \\
(0.106 \pm 0.009-0.167 \pm 0.014)\end{array}$ & 142.9 & $\begin{array}{c}19,4 \\
(15.1-23.9)\end{array}$ \\
\hline Fucus vesiculosus & $\begin{array}{c}0.040 \pm 0.006^{c} \\
(0.023 \pm 0.003-0.049 \pm 0.007)\end{array}$ & $<38.7$ & $\begin{array}{c}<1.5 \\
(0.9-1.9)\end{array}$ \\
\hline Fucus serratus & $\begin{array}{c}0.040 \pm 0.004^{\mathrm{c}} \\
(0.023 \pm 0.002-0.049 \pm 0.005)\end{array}$ & 71.9 & $\begin{array}{c}2.9 \\
(1.7-3.5)\end{array}$ \\
\hline Ascophyllum nodosum & $\begin{array}{c}0.014 \pm 0.003^{\mathrm{d}} \\
(0.008 \pm 0.001-0.017 \pm 0.003)\end{array}$ & 48.1 & $\begin{array}{c}0.7 \\
(0.4-0.8)\end{array}$ \\
\hline Laminaria digitata & $\begin{array}{c}0.006 \pm 0.001^{\mathrm{d}} \\
(0.004 \pm 0.001-0.008 \pm 0.002)\end{array}$ & 69.4 & $\begin{array}{c}0.4 \\
(0.3-0.6)\end{array}$ \\
\hline
\end{tabular}

being less than the lowest observed tissue P-concentration. Critical P-concentrations (Table 3) ranged from $38.7 \mu \mathrm{mol} \mathrm{P} \mathrm{g}{ }^{-1} \mathrm{DW}(0.12 \% \mathrm{DW})$ in $F$. vesiculosus to $142.9 \mu \mathrm{mol} \mathrm{P} \mathrm{g}^{-1} \mathrm{DW}(0.44 \% \mathrm{DW})$ in Ceramium rubrum, but were not systematically related to maximum growth rate when compared across species (Pearson correlation; $\mathrm{R}=0.452, \mathrm{p}=0.37$ ). In contrast, species specific P-requirements needed to support maximum growth rate varied almost 50-fold across species, ranging from $0.4 \mu \mathrm{mol} \mathrm{P} \mathrm{g}^{-1} \mathrm{DW} \mathrm{d}^{-1}$ in slowgrowing Laminaria digitata to $19.4 \mu \mathrm{mol} \mathrm{P} \mathrm{g}^{-1} \mathrm{DW} \mathrm{d}^{-1}$ in fast-growing C. rubrum (Table 3).

\section{P-uptake kinetics and the balance between requirements and uptake}

Plots of uptake rates versus phosphate concentrations showed saturation kinetics and were described by the Monod model (Fig. 3). Initial uptake rates measured during the first $30 \mathrm{~min}$ of exposure to phosphate were not different from those obtained between 30 and 180 min after exposure (at similar concentrations) so all data (from each experiment) were collapsed to obtain one set of kinetic parameters per species (Table 4). Maximum rates of P-uptake ( $\left.V_{\max }\right)$ varied 20-fold among algal species and ranged from $0.45 \mu \mathrm{mol} \mathrm{P} \mathrm{g}^{-1}$ DW $\mathrm{h}^{-1}$ in Ascophyllum nodosum to $8.00 \mu \mathrm{mol} \mathrm{P} \mathrm{g}^{-1}$ $\mathrm{DW} \mathrm{h}^{-1}$ in Ceramium rubrum (Table 4 ). $V_{\max }$ of the 2 ephemeral species (i.e. Ulva lactuca and C. rubrum) were markedly higher than for the 4 perennial species. Half saturation constants $\left(\mathrm{K}_{\mathrm{m}}\right)$ varied less than $V_{\max }$ across species, but were higher for the ephemeral species. The affinity for phosphorus at low substrate concentrations (i.e. $V_{\max } / \mathrm{K}_{\mathrm{m}}$ ) varied 18 -fold among species, ranging from $0.12 \mu \mathrm{mol} \mathrm{P} \mathrm{g}^{-1} \mathrm{DW} \mathrm{h}^{-1}(\mu \mathrm{M} \mathrm{P})^{-1}$ in A. nodosum to $2.13 \mu \mathrm{mol} \mathrm{P} \mathrm{g}^{-1} \mathrm{DW} \mathrm{h}^{-1}(\mu \mathrm{M} \mathrm{P})^{-1}$ in $C$. rubrum, the 2 ephemerals (C. rubrum and U. lactuca) having a higher affinity for DIP than the 4 perennial species.

DIP concentrations needed to allow uptake rates that could balance $\mathrm{P}$-demands at maximum growth rate varied considerably among species (Table 5). Laminaria digitata, Fucus vesiculosus and Ascophyllum nodosum required $<0.1,0.2$ and $0.3 \mu \mathrm{M}$ DIP in the water to satisfy their maximum P-demands through uptake. Ambient DIP concentrations that low were only observed for a relatively short period (Fig. 1). Fucus serratus and Ceramium rubrum required between 0.3 and $0.4 \mu \mathrm{M}$ DIP to satisfy their requirements for fast growth, so these species were potentially P-limited for about 25 to $33 \mathrm{wk}$ of the year. Ulva lactuca required much higher concentrations than all other species; about $0.8 \mu \mathrm{M}$ DIP to satisfy its requirement for maximum growth. Ambient DIP concentrations were only that high during winter, suggesting potential Plimitation of $U$. lactuca growth for most of the year.

The actual period where uptake of $\mathrm{P}$ would be insufficient to meet P-demands is however much shorter than calculated above because algae do not grow at maximum rates for very long. Growth, and thus Prequirements, should be relatively low in fall, winter and spring due to low insolation. Assuming that the calculated growth rates are approximately linearly 
related to daily light availability we simulated seasonal variations in growth and P-requirements (Fig. 4) to get a more realistic picture of the balance between Puptake and requirements. The period where these simulated P-requirements exceeded estimated uptake of DIP was markedly shorter than when calculated from maximum growth rate and P-requirement, ranging from 0 to $7 \mathrm{wk}$ in Laminaria digitata and Ascophyllum nodosum to 24 to $27 \mathrm{wk}$ in Ceramium rubrum and Ulva lactuca (Table 5).
P-storage. The importance of P-storage depends on the absolute amount of excess $P$ (i.e. the difference between critical and maximum P-concentrations) and the growth rate by which this phosphorus is diluted by growth (Table 6). The absolute amount of stored $\mathrm{P}$ ranged from $41.9 \mu \mathrm{mol} \mathrm{P} \mathrm{g}^{-1} \mathrm{DW}$ in Ascophyllum nodosum to $>134.3 \mu \mathrm{mol} \mathrm{P} \mathrm{g}^{-1}$ DW in Fucus vesiculosus, and did not correlate with maximum growth rate of the algae (Pearson correlation; $\mathrm{R}=-0.272, \mathrm{p}=0.60$ ). The storage capacity, i.e. the time that these stores could
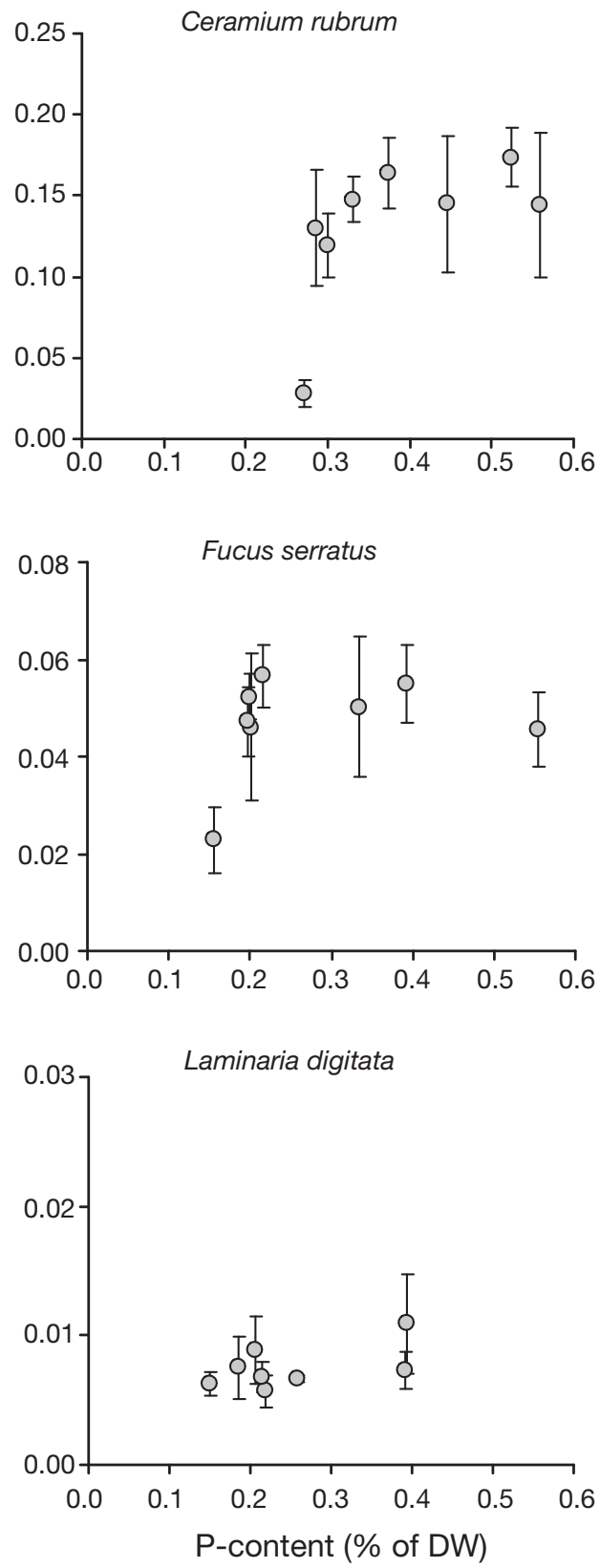

Fig. 2. Growth rates and tissue P-concentrations. Calculated relative growth rate (RGR) as a function of tissue P-concentration in 6 species of macroalgae. Data are mean $\pm 1 \mathrm{SD}(\mathrm{n}=4)$ 



Fig. 3. P-uptake kinetics. The relationship between uptake rate of inorganic phosphorus and DIP concentration in 6 species of macroalgae. Uptake rates for each species include data from 6 specimens

support maximum or simulated (seasonal) growth rates without supplementary uptake of external $\mathrm{P}$, varied markedly among species. Stored P could only support growth for 1 to $2 \mathrm{wk}$ in Ulva lactuca and Ceramium rubrum, for 8 to $10 \mathrm{wk}$ in the 2 Fucus species and for more than 12 and $19 \mathrm{wk}$ in A. nodosum and Laminaria digitata, respectively. Stored P could of course support growth for longer time if uptake of DIP from the water (although at slow rates) was taken into account (U. lactuca: 4 wk; C. rubrum: 5 wk; F. vesiculosus: $12 \mathrm{wk}_{;} F$. serratus: $11 \mathrm{wk}$; A. nodosum: $22 \mathrm{wk}$ and L. digitata: $>52 \mathrm{wk})$.

\section{DISCUSSION}

Low concentrations of DIP and high DIN:DIP ratios in the seawater suggest that the central part of Oslofjord was primarily P limited during summer, although concentrations of dissolved inorganic nutrients are a weak indicator of nutrient limitation (Dodds 2003). Low tissue concentrations of P (i.e. 0.17 to $0.31 \%$ DW), high tissue concentrations of N (1.86 to $4.94 \%$ DW) and relatively high NP-ratios (24.9 to 78.9) in the algae confirmed, however, that at least some of the algae were P-limited during summer (Duarte 1992, Lapointe et al. 1992). 
Table 4. Phosphorus uptake kinetics ( $V_{\max }$ and $\mathrm{K}_{\mathrm{m}}$ ) for 6 species of macroalgae. The kinetic parameters were determined in laboratory experiments using a combination of the 'multiple flask method' and the 'depletion method' (Pedersen 1995). Dara are mean $\pm \mathrm{SE}$

\begin{tabular}{|c|c|c|c|c|}
\hline Species & $\begin{array}{c}V_{\max } \\
\left(\mu \mathrm{mol} \mathrm{P} \mathrm{g}^{-1} \mathrm{DW} \mathrm{h}^{-1}\right)\end{array}$ & $\begin{array}{c}\mathrm{K}_{\mathrm{m}} \\
(\mu \mathrm{M} \mathrm{P})\end{array}$ & $V_{\max } / \mathrm{K}_{\mathrm{m}}$ & $\mathrm{R}^{2}$ \\
\hline Ulva lactuca & $4.15 \pm 0.79$ & $5.58 \pm 2.00$ & 0.74 & 0.78 \\
\hline Ceramium rubrum & $8.00 \pm 0.88$ & $3.75 \pm 0.81$ & 2.13 & 0.87 \\
\hline Fucus vesiculosus & $1.26 \pm 0.16$ & $4.17 \pm 1.07$ & 0.30 & 0.91 \\
\hline Fucus serratus & $0.82 \pm 0.05$ & $2.14 \pm 0.34$ & 0.38 & 0.87 \\
\hline Ascophyllum nodosum & $0.45 \pm 0.05$ & $3.75 \pm 0.88$ & 0.12 & 0.78 \\
\hline Laminaria digitata & $0.70 \pm 0.12$ & $3.73 \pm 1.50$ & 0.19 & 0.61 \\
\hline
\end{tabular}

Table 5. The balance between P-uptake and P-requirements in 6 species of macroalgae. DIP-concentration needed for uptake to balance P-requirements at maximum growth rate, maximum period of potential P-limitation and simulated period of P-limitation (based on seasonal variation in growth rate). Parentheses: range of DIN concentrations and periods of potential P-limitation obtained by using a range of $\mathrm{PQ}$-values to estimate growth rate from photosynthesis

\begin{tabular}{|c|c|c|c|}
\hline Species & $\begin{array}{c}\text { DIP } \\
\text { concentration } \\
\text { required } \\
(\mu \mathrm{M})\end{array}$ & $\begin{array}{l}\text { Maximum } \\
\text { P-limitation } \\
\text { period } \\
\text { (wk) }\end{array}$ & $\begin{array}{l}\text { Simulated } \\
\text { P-limitation } \\
\text { period } \\
(\mathrm{wk})\end{array}$ \\
\hline Ulva lactuca & $\begin{array}{c}0.82 \\
(0.71-0.97)\end{array}$ & $\begin{array}{c}51 \\
(48-51)\end{array}$ & $\begin{array}{c}27 \\
(27-28)\end{array}$ \\
\hline Ceramium rubrum & $\begin{array}{c}0.42 \\
(0.32-0.53)\end{array}$ & $\begin{array}{c}33 \\
(28-40)\end{array}$ & $\begin{array}{c}24 \\
(24-24)\end{array}$ \\
\hline Fucus vesiculosus & $\begin{array}{c}0.22 \\
(0.13-0.28)\end{array}$ & $\begin{array}{c}25 \\
(7-30)\end{array}$ & $\begin{array}{c}16 \\
(3-19)\end{array}$ \\
\hline Fucus serratus & $\begin{array}{c}0.37 \\
(0.20-0.46)\end{array}$ & $\begin{array}{c}30 \\
(12-34)\end{array}$ & $\begin{array}{c}19 \\
(5-24)\end{array}$ \\
\hline Ascophyllum nodosur & $\begin{array}{l}m \quad 0.26 \\
(0.14-0.30)\end{array}$ & $\begin{array}{c}20 \\
(7-25)\end{array}$ & $\begin{array}{c}7 \\
(3-17)\end{array}$ \\
\hline Laminaria digitata & $\begin{array}{c}0.09 \\
(0.07-0.14)\end{array}$ & $\begin{array}{c}0 \\
(0-6)\end{array}$ & $\begin{array}{c}0 \\
(0-0)\end{array}$ \\
\hline
\end{tabular}

Primary producers in temperate and siliciclastic coastal waters are normally considered N-limited whereas sub-tropical and tropical carbonate-rich waters are expected to be P-limited (Howarth 1988, Lapointe et al. 1992, Howarth \& Marino 2006). P-limitation may also occur in temperate and siliciclastic coastal waters impacted by anthropogenic nutrient loading, especially after effective P-removal from wastewater (Conley et al. 2000, Howarth \& Marino 2006). Källqvist (1988) and Paasche \& Erga (1988) claimed that the phytoplankton in Oslofjord has become P-limited during summer due to large transport of $\mathrm{N}$ from agricultural areas and recent improvements of P-removal from urban waste-water. While phytoplankton growth and biomass is often limited by low availability of nutrients, nutrient limitation is much more variable among macroalgae. Slow-growing macroalgae may be nutrient replete during periods of low nutrient availability, while at the same time faster-growing macroalgae may suffer severe nutrient limitation (e.g. Duarte 1995, Pedersen \& Borum 1996, 1997, Valiela et al. 1997). Inter-specific variations in the response to nutrient richness among macroalgae are largely based on differences in inherent growth rate and nutrient dynamics. Accordingly, we found that tissue P-concentrations, the balance between P-uptake and requirements, and the P-storage capacity varied systematically among the 3 groups of algae (i.e. algae of fast, intermediate and slow growth) examined here.

The growth rates used to estimate Prequirements and storage capacity were calculated from photosynthetic rates. Ranges of PQ-ratios representative for green, red and brown macroalgae, respectively, were used to convert photosynthetic rates to growth, since we were unable to find species specific PQ-ratios in the literature. Growth rates, and hence the estimated P-requirements and storage capacities, are consequently determined with some uncertainty, which could potentially affect our conclusions. The growth rates that we calculated from photosynthetic rates, and the interspecific variation among them, nevertheless resemble measured in situ growth rates of the same, or comparable, species (Pedersen \& Borum 1996, M. F. Pedersen unpubl. data). More importantly, the inter-specific differences in calculated growth rates were much larger (30-fold range) than the uncertainty related to the estimates of individual growth rates. Our estimated differences in P-requirements and storage capacity are consequently quite robust, and even substantial uncertainty related to the estimated growth rates would not affect the overall conclusions.

PQ-ratios of individual algae may further vary as a result of nutrient limitation (Turpin 1991). Nutrient limitation is thought to raise PQ because energy is allocated from growth to nutrient uptake. If true, this could affect our estimates of critical P-limits which would be 

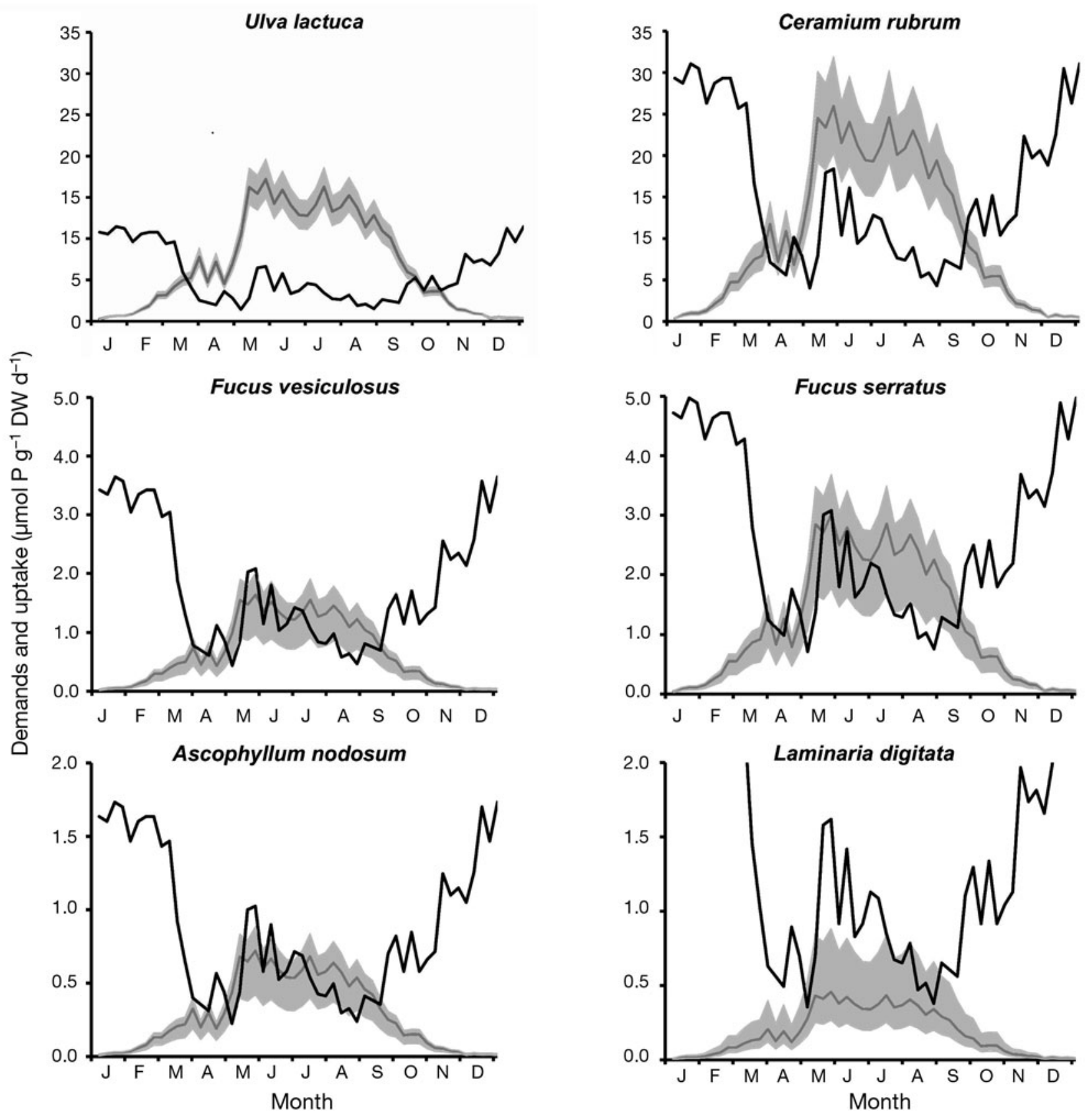

Fig. 4. Estimated uptake and requirements of P. Seasonal balance between uptake of dissolved inorganic P as estimated from observed uptake kinetics and concentrations of DIP (black line) and simulated P-requirements (grey line and shaded area) in 6 species of macroalgae. P-requirements are represented by a range based on the range of PQ-values used to estimate growth from photosynthetic rates

underestimated. Several studies have however shown that macroalgal photosynthesis and growth are affected more or less similarly by nutrient limitation (e.g. Lapointe 1987, Pedersen 1995, McGlathery et al. 1996), which makes sense since pigment concentrations, enzyme levels etc. are affected almost immediately by nutrient limitation. The critical P-limits were used to estimate P-requirements which also depended on growth rate. Growth rates differed much more (50fold) than critical P-limits (3-fold) among species, meaning that small uncertainties related to the critical P-limits are relatively unimportant for our comparison.

Ulva lactuca and Ceramium rubrum probably suffered P-limitation for a long period extending from spring to late summer in Oslofjord. This is because their affinity for DIP was too low to satisfy P-demands 
Table 6. Critical and maximum tissue concentrations of $\mathrm{P}$ (mean $\pm \mathrm{SD}$ ), absolute amount of stored P and estimated storage capacity that stored $\mathrm{P}$ can support maximum and simulated growth rates, respectively. Parentheses: range of storage capacities obtained by using a range of PQ-values to estimate growth rate from photosynthesis

\begin{tabular}{|c|c|c|c|c|c|}
\hline & $\begin{array}{c}\text { Critical tissue } \\
\text { P-concentration }\end{array}$ & $\begin{array}{l}\text { Maximum tissue } \\
\text { P-concentration } \\
\left(\mu \mathrm{mol} \mathrm{P} \mathrm{g}^{-1} \mathrm{DW}\right)\end{array}$ & $\begin{array}{l}\text { Absolute } \\
\text { P-store }\end{array}$ & $\begin{array}{l}\text { Storage capacity } \\
\text { at max. growth } \\
\text { rate (wk) }\end{array}$ & $\begin{array}{l}\text { Storage capacity at } \\
\text { simulated seasonal } \\
\text { growth rate (wk) }\end{array}$ \\
\hline Ulva lactuca & 65.5 & $125 \pm 20$ & 59.5 & $\begin{array}{c}2 \\
(2-2)\end{array}$ & $\begin{array}{c}4 \\
(3-4)\end{array}$ \\
\hline Ceramium rubrum & 142.9 & $186 \pm 22$ & 43.1 & $\begin{array}{c}1 \\
(1-2)\end{array}$ & $\begin{array}{c}5 \\
(4-7)\end{array}$ \\
\hline Fucus vesiculosus & $<38.7$ & $173 \pm 7$ & $>134.3$ & $\begin{array}{c}>10 \\
(10-13)\end{array}$ & $\begin{array}{c}>12 \\
(11->52)\end{array}$ \\
\hline Fucus serratus & 71.9 & $161 \pm 20$ & 89.1 & $\begin{array}{c}8 \\
(7-11)\end{array}$ & $\begin{array}{c}11 \\
(11->52)\end{array}$ \\
\hline Ascophyllum nodosum & 48.1 & $90 \pm 9$ & 41.9 & $\begin{array}{c}12 \\
(11-16)\end{array}$ & $\begin{array}{c}22 \\
(15->52)\end{array}$ \\
\hline Laminaria digitata & 69.4 & 133 & 63.6 & $\begin{array}{c}19 \\
(17-31)\end{array}$ & $\begin{array}{c}>52 \\
(>52->52)\end{array}$ \\
\hline
\end{tabular}

under low nutrient conditions and because their P-storage capacity was too small to support growth for more than a few days. C. rubrum required substantially lower concentrations of DIP in the water than U. lactuca to satisfy its P-demand, but would nevertheless experience P-limitation for almost as long as U. lactuca because the concentration of DIP dropped so much and so fast in spring and stayed low until October. The 2 Fucus species required almost the same concentrations of DIP as C. rubrum to meet their demands. Uptake of phosphorus by these species was therefore also insufficient to meet their P-demands during most of the growth season. Both Fucus species had in contrast large P-storage capacities that could support growth for several weeks, even if no dissolved phosphorus was available in the water. Species of intermediate growth rates (i.e. Fucus) were therefore likely to remain more or less unaffected by low availability of DIP during most of the growth season.

At the other extreme, slow-growing Ascophyllum nodosum and Laminaria digitata had very low Prequirements and both were able to obtain sufficient DIP to satisfy their P-demand during most of the year. Both species had further a substantial P-storage capacity allowing growth to proceed for several months, even without exploiting external P-sources. Low Prequirements relative to their $\mathrm{P}$-uptake capacity and a high storage capacity ensured that $A$. nodosum and $L$. digitata did not experience P-limitation under ambient conditions at all.

The observed variation in the chance of facing Plimitation in response to changes in P-availability was caused by species-specific variations in P-dynamics including variations in P-requirements, uptake kinetics and storage capacities. Phosphorus is essential to all plants and algae, but the P-demands per unit time and biomass differed considerably among the macroalgae examined here. The 2 fast-growing species (Ulva lactuca and Ceramium rubrum) required 4 to 5 fold and 10 to 20 fold more P per unit biomass and time than species of intermediate and slow growth, respectively. Requirements for phosphorus depend on realized growth rates and critical P-concentrations of the algae. We expected critical tissue concentrations to be higher in algae with fast inherent growth because such species should contain more metabolically active, and less supportive, tissues than slower growing species (Duarte 1995), but we were unable to demonstrate such a relationship. The correlation between Prequirement and growth rate relied therefore mainly on inter-specific variations in growth rate (about 30fold among species) and less on variations in critical Pcontent. A similar correlation between N-requirements and growth rate was previously reported by Pedersen \& Borum (1996) who compared the N-dynamics of fastgrowing and slow-growing macroalgae. The positive relationship between nutrient requirements and inherent growth rate suggests that fast-growing algae are more susceptible to nutrient limitation than slowgrowing species unless they can acquire nutrients more efficiently from the surrounding water.

Growth rate and nutrient uptake rate are both positively correlated to relative surface area of algae (Odum et al. 1958, Nielsen \& Sand-Jensen 1990, Hein et al. 1995) meaning that small (thin) algae grow and take up nutrients faster per unit biomass and time than 
larger (thicker) species. Our data conform to these observations since Ceramium rubrum and Ulva lactuca (both thin and fast-growing), took up DIP at rates that were about 6 times faster than the Fucus species, and ca. 12 times faster than the slow-growing Ascophyllum nodosum and Laminaria digitata. The uptake kinetics reported here, and the variation across species with different growth rate, thickness and thallus morphology resemble those previously reported in the literature (e.g. Odum et al. 1958, Gordon et al. 1981, Wallentinus 1984, O'Brien \& Wheeler 1987, Björnsäter \& Wheeler 1990, Hurd \& Dring 1990, Lavery \& McComb 1991, Runcie et al. 2004) confirming that the overall relationship between P-uptake rate, organism size (i.e. thickness and thallus morphology) and inherent growth rate is a general pattern.

Ulva lactuca and Ceramium rubrum took up P much faster than the slower growing species, but their affinity to DIP was not sufficient to ensure uptake that could satisfy their demand during periods of low DIP-concentrations. On the other hand, estimated uptake of DIP exceeded the P-requirements of most algae in fall, winter and early spring (Fig. 4). This 'luxury' uptake may lead to an accumulation of $\mathrm{P}$ above the critical Pcontent; this accumulated $\mathrm{P}$ can subsequently be used to support growth in late spring and summer when Prequirements might not be satisfied through uptake of $P$ from external sources. The storage capacity of $\mathrm{P}$ varied among species and seemed to be important for the observed variation in the response to low P-availability when comparing fast-growing and slow-growing algae. Species with a more or less similar relationship between P-uptake and requirements (e.g. Ceramium rubrum, Fucus vesiculosus and Fucus serratus) still differed very much in their response to low availability of DIP, because the slower growing Fucus species could rely on stored $\mathrm{P}$ for much longer than C. rubrum.

In conclusion, we found marked and systematic differences in P-requirements, uptake kinetics and Pstorage capacity when comparing fast-growing and slow-growing macroalgae. Species with fast growth could not rely on stored $\mathrm{P}$ for long, and their performance therefore required continuous availability and supply of DIP, whereas algae of intermediate and slow growth relied more on stored P during periods of low DIP availability. Fast-growing algae were therefore more likely to respond to long term changes in nutrient availability, i.e. an increase in abundance at increasing nutrient richness and vice versa. Our findings are complementary to those found in a comparative analysis of $\mathrm{N}$-dynamics among temperate seaweeds (Pedersen \& Borum 1996, 1997), showing that fast-growing and slow-growing macroalgae respond more or less similarly to changes in the availability of both $\mathrm{N}$ and $\mathrm{P}$. Accordingly, increasing P-loading in P-limited systems should have similar consequences as increasing $\mathrm{N}$ loading in N-limited coastal areas where slow-growing macroalgae are gradually replaced by faster growing ephemeral forms (e.g. Borum \& Sand-Jensen 1996, Fletcher 1996, Valiela et al. 1997).

Acknowledgements. This study was funded by the European Commission through the MAST III program (contract MAS3CT97-0153) and by the MARICULT/Norsk Hydro Program. We thank 3 anonymous referees for their useful and constructive comments on an earlier version of the manuscript.

\section{LITERATURE CITED}

Björnsäter BR, Wheeler PA (1990) Effect of nitrogen and phosphorus supply on growth and tissue composition of Ulva fenestra and Enteromorpha intestinalis (Ulvales, Chlorophyta). J Phycol 26:603-611

Bokn TL, Murray SN, Moy FE, Magnusson JB (1992) Changes in fucoid distributions and abundances in the inner Oslofjord, Norway: 1974-80 versus 1988-90. Acta Phytogeogr Suec 78:117-124

Bokn TL, Hoell EE, Kersting K, Moy FE, Sørensen K (2001) Methods applied in the large littoral mesocosms study of nutrient enrichment in rocky shore ecosystems. Cont Shelf Res 21:1925-1936

Bokn TL, Duarte CM, Pedersen MF, Marba N and others (2003) The response of experimental rocky shore communities to nutrient addition. Ecosystems 6:577-594

$>$ Borum J, Sand-Jensen K (1996) Is total primary production in shallow coastal marine waters stimulated by nitrogen loading? Oikos 76:406-410

Buesa RJ (1980) Photosynthetic quotient of marine plants. Photosynthetica 14:337-342

Conley DJ, Kaas H, Møhlenberg F, Rasmussen B, Windolf J (2000) Characteristics of Danish estuaries. Estuaries 23:820-837

Dodds WK (2003) Misuse of inorganic N and soluble reactive $\mathrm{P}$ concentrations to indicate nutrient status of surface waters. J N Am Benthol Soc 22:171-181

Duarte CM (1992) Nutrient concentrations of aquatic plants: patterns across species. Limnol Oceanogr 37:882-889

Duarte CM (1995) Submerged aquatic vegetation in relation to different nutrient regimes. Ophelia 41:87-112

Eriksson BK, Johansson G, Snoeijs P (1998) Long-term changes in the sub-littoral zonation of brown algae in the southern Bothnian Sea. Eur J Phycol 33:241-249

Fletcher RL (1996) The occurrence of 'green tides' - a review. In: Schramm W, Nienhuis PH (eds) Marine benthic vegetation: recent changes and the effects of eutrophication. Springer-Verlag, Berlin, p 7-43

> Gordillo FJL, Dring MJ, Savidge G (2002) Nitrate and phosphate uptake characteristics of three species of brown algae cultured at low salinity. Mar Ecol Prog Ser 234:111-118

Gordon DM, Birch PB, McComb AJ (1981) Effects of inorganic phosphorus and nitrogen on the growth of an estuarine Cladophora in culture. Bot Mar 24:93-106

Hanisak MD (1979) Nitrogen limitation of Codium fragile spp. tomentosoides as determined by tissue analysis. Mar Biol 50:333-337

Harrison PJ, Parslow JS, Conway HL (1989) Determination of nutrient uptake kinetic parameters: a comparison of methods. Mar Ecol Prog Ser 52:301-312

$>$ Healey FP (1980) Slope of the Monod equation as an indicator of advantage in nutrient competition. Microb Ecol 5:281-286 
Hein M, Pedersen MF, Sand-Jensen K (1995) Size-dependent nitrogen uptake in micro- and macroalgae. Mar Ecol Prog Ser 118:247-253

Howarth RW (1988) Nutrient limitation of net primary production in marine ecosystems. Annu Rev Ecol Syst 19:89-110

Howarth RW, Marino R (2006) Nitrogen is the limiting nutrient for eutrophication in coastal marine ecosystems: evolving views over three decades. Limnol Oceanogr 51:364-376

Hurd CL, Dring MJ (1990) Phosphate uptake by intertidal algae in relation to zonation and season. Mar Biol 107:281-290

Källqvist T (1988) Nitrogen or phosphorus: What is limiting nutrient in coastal areas? Examples from Norwegian fjords. Vatten 44:11-18

Karez R, Engelbert S, Kraufvelin P, Pedersen MF, Sommer U (2004) Biomass response and changes in composition of ephemeral macroalgal assemblages along an experimental gradient of nutrient enrichment. Aquat Bot 78:103-117

Kautsky N, Kautsky H, Kautsky U, Waern M (1986) Decreased depth penetration of Fucus vesiculosus since the 1940's indicates eutrophication of the Baltic Sea. Mar Ecol Prog Ser 28:1-8

Kraufvelin P, Moy FE, Christie H, Bokn TL (2006) Nutrient addition to experimental rocky shore communities revisited: delayed responses, rapid recovery. Ecosystems 9:1076-1093

Kraufvelin P, Lindholm A, Pedersen MF, Kirkerud LA, Bonsdorff E (2010) Biomass, diversity and production of rocky shore macroalgae at two nutrient enrichment and wave action levels. Mar Biol 157:29-47

Kronvang B, Jeppesen E, Conley DJ, Søndergaard M, Larsen SE, Ovesen NB, Carstensen J (2005) Nutrient pressures and ecological responses to nutrient loading reductions in Danish streams, lakes and coastal waters. J Hydrol (Amst) 304:274-288

Lapointe BE (1987) Phosphorus- and nitrogen-limited photosynthesis and growth of Gracilaria tikvahiae (Rhodophyceae) in the Florida Keys: an experimental field study. Mar Biol 93:561-568

Lapointe BE, Littler MM, Littler DS (1992) Nutrient availability to marine macroalgae in siliciclastic versus carbonaterich coastal waters. Estuaries 15:75-82

Lavery PS, McComb AJ (1991) The nutritional eco-physiology of Chaetomorpha linum and Ulva rigida in Peel inlet, Western Australia. Bot Mar 34:251-260

> Manley SL, North WJ (1984) Phosphorus and the growth of juvenile Macrocystis pyrifera (Phaeophyta) sporophytes. J Phycol 20:389-393

McGlathery KJ, Pedersen MF, Borum J (1996) Changes in intracellular nitrogen pools and feedback controls on nitrogen uptake in Chaetomorpha linum (Chlorophyta). J Phycol 32:393-401

- Mercado JM, Avilés A, Benítez E, Carrasco M, Palomo L, Clavero V, Niell FX (2003) Photosynthetic production of Ulva rotundata Bliding estimated by oxygen and inorganic carbon exchange measurements in the field. Bot Mar 46:342-349

Nielsen SL, Sand-Jensen K (1990) Allometric scaling of maximal photosynthetic growth rate to surface/volume ratio. Limnol Oceanogr 25:177-180

Nielsen SL, Sand-Jensen K, Borum J, Gertz-Hansen O (2002a) Phytoplankton, nutrients, and transparency in Danish coastal waters. Estuaries 25:930-937

> Nielsen SL, Sand-Jensen K, Borum J, Gertz-Hansen O (2002b) Depth colonization of eelgrass (Zostera marina) and macroalgae as determined by water transparency in Danish coastal waters. Estuaries 25:1025-1032
Nixon SW (1995) Coastal marine eutrophication: a definition, social causes, and future concerns. Ophelia 41:199-220

O'Brien MC, Wheeler PA (1987) Short-term uptake of nutrients by Enteromorpha prolifera (Chlorophyceae). J Phycol 23:547-556

Odum EP, Kuenzler EJ, Blunt MX (1958) Uptake of ${ }^{32} \mathrm{P}$ and primary production in marine benthic algae. Limnol Oceanogr 3:340-345

Paasche E, Erga SR (1988) Phosphorus and nitrogen limitation of phytoplankton in the inner Oslofjord (Noway). Sarsia 73:229-243

Pedersen MF (1994) Transient ammonium uptake in the macroalga Ulva lactuca (Chlorophyta) - nature, regulation, and the consequences for choice of measuring technique. J Phycol 30:980-986

Pedersen MF (1995) Nitrogen limitation of photosynthesis and growth across aquatic plant communities in a Danish estuary (Roskilde Fjord). Ophelia 41:261-272

Pedersen MF, Borum J (1996) Nutrient control of algal growth in estuarine waters. Nutrient limitation and the importance of nitrogen requirements and nitrogen storage among phytoplankton and species of macroalgae. Mar Ecol Prog Ser 142:261-272

Pedersen MF, Borum J (1997) Nutrient control of estuarine macroalgae: growth strategy and the balance between nitrogen requirements and uptake. Mar Ecol Prog Ser 161:155-163

Rosenberg G, Littler DS, Littler MM, Oliveira EC (1995) Primary production and photosynthetic quotients of seaweeds from Sao Paulo State, Brazil. Bot Mar 38:369-377

Rueness J, Fredriksen S (1991) An assessment of possible pollution effects on the benthic algae of the outer Oslofjord, Norway. Oebalia 17:223-235

Runcie JW, Ritchie RJ, Larkum AWD (2004) Uptake kinetics and assimilation of phosphorus by Catenella nipae and Ulva lactuca can be used to indicate ambient phosphate availability. J Appl Phycol 16:181-194

Sand-Jensen K, Borum J (1991) Interaction among phytoplankton, periphyton, and macrophytes in temperate freshwaters and estuaries. Aquat Bot 41:137-176

Schramm W (1999) Factors influencing seaweed responses to eutrophication: some results from EU-project EUMAC. J Appl Phycol 11:69-78

Sfriso A, Marcomini A (1996) Italy — the Lagoon of Venice. In: Schramm W, Nienhuis PH (eds) Marine benthic vegetation: recent changes and the effects of eutrophication. Springer-Verlag, Berlin, p 339-368

Strickland JD, Parsons TR (1968) A practical handbook of seawater analysis. Bull Fish Res Board Can. No 167

Thomas DN, Wiencke C (1991) Photosynthesis, dark respiration and light independent carbon fixation of endemic Antarctic macroalgae. Polar Biol 11:329-337

> Turpin DH (1991) Effects of inorganic N availability on algal photosynthesis and carbon metabolism. J Phycol 27:14-20

Valiela I, McClelland J, Hauxwell J, Behr P, Hersh D, Foreman K (1997) Macroalgal blooms in shallow estuaries: Controls and ecophysiological and ecosystem consequences. Limnol Oceanogr 42:1105-1118

Vogt H, Schramm W (1991) Conspicuous decline of Fucus in Kiel Bay (western Baltic): What are the causes? Mar Ecol Prog Ser 69:189-194

Wallentinus I (1984) Comparisons of nutrient uptake rates for Baltic macroalgae with different thallus morphologies. Mar Biol 80:215-225

Williams PJ leB, Robertson JE (1991) Overall planktonic oxygen and carbon dioxide metabolisms: the problem of reconciling observations and calculations of photosynthetic quotients. J Plankton Res 13:153-169 